2020-09-01

\title{
Arsenic speciation and its DNA fractionation in the rice plant: Oryza sativa
}

\section{Foulkes, ME}

http://hdl.handle.net/10026.1/16443

\author{
10.1039/d0ja00141d \\ Journal of Analytical Atomic Spectrometry
}

All content in PEARL is protected by copyright law. Author manuscripts are made available in accordance with publisher policies. Please cite only the published version using the details provided on the item record or document. In the absence of an open licence (e.g. Creative Commons), permissions for further reuse of content should be sought from the publisher or author. 
Check for updates

Cite this: J. Anal. At. Spectrom., 2020, 35, 1989

Received 3rd April 2020

Accepted 8th July 2020

DOI: 10.1039/d0ja00141d

rsc.li/jaas

\title{
Arsenic speciation and its DNA fractionation in the rice plant Oryza sativa
}

\author{
Mike E. Foulkes, ${ }^{a}$ Bashdar A. Sadee ${ }^{b}$ and Steve J. Hill (D) *a
}

The transport of arsenic from soil through to edible crop is important when assessing the potential health risks from a food source. Samples of soil, irrigation water and the rice plant, Oryza sativa, were collected from an agricultural site in the Middle East. Total As, its speciation and DNA fractionation were evaluated using HPLC-ICP-MS in samples which included the root, stem, leaf and grain of the rice plant. Methodology was validated through the use of CRMs. The highest concentration of As was found in the root of the plant and the lowest in the grain. The concentrations found for As were: soil (aqua-regia extractable; $\left.2.88 \mu \mathrm{g} \mathrm{g}^{-1}\right)$, irrigation water $\left(0.58 \mu \mathrm{g} \mathrm{L}^{-1}\right)$, roots $\left(8.28 \mu \mathrm{g} \mathrm{g}^{-1}\right)$, stem $\left(4.00 \mu \mathrm{g} \mathrm{g}^{-1}\right)$, leaves $\left(2.93 \mu \mathrm{g} \mathrm{g}^{-1}\right)$ and grain $\left(1.02 \mu \mathrm{g} \mathrm{g}^{-1}\right)$. Levels of inorganic $\mathrm{As}^{\vee}$ and $A s^{\prime \prime \prime}$ were identified in the soil and plant material, while organo-arsenic species (DMA, MMA) were below the limit of detection. The 'plant available' levels of As in the soil (14\%) were determined as part of a full, validated BCR three-step sequential extraction procedure. Since As can behave as a phosphate analogue, a method was developed for the extraction of vegetative DNA to determine the different forms of As associated with, or integrated within, the DNA fractions. Measurement of As in the DNA extracts were above the LOD $\left(0.019 \mu \mathrm{g} \mathrm{kg}^{-1}\right)$ for the root, stem and leaf samples. The concentration of both weakly and strongly associated As with DNA obtained from the root, stem and leaf decreased with decreasing total As concentrations. A narrow, near-constant ratio for the strongly associated As value (As/total As DNA) in all root, stem and leaf DNA samples $(41.3 \pm 0.3 \%)$ was further evidence for the incorporation of As into the DNA.

\section{Introduction}

Arsenic speciation is an essential parameter when assessing As uptake mechanisms by plants and animals and our understanding of the term 'toxicity'. In general, inorganic As species, InAs ${ }^{\text {III }}$ and InAs ${ }^{\mathrm{V}}$, are more toxic than organic As species. It is well known that $\operatorname{InAs}^{\mathrm{V}}$, which is a phosphate analogue, can occur as $\mathrm{H}_{2} \mathrm{AsO}_{4}{ }^{-}$or $\mathrm{HAsO}_{4}{ }^{2-}$ dependent upon $\mathrm{pH}$, and may enter the root plant symplast through phosphate transport proteins. $^{\mathbf{1 , 2}}$ Inorganic $\mathrm{As}^{\mathrm{III}}$ is considered to be a silicic acid analogue, existing as $\mathrm{H}_{3} \mathrm{AsO}_{3}$ at $\mathrm{pH}<8$, and it is documented to enter into the root symplast and loaded into the xylem system through the aquaporin channels LSi1 and LSi2 placed along the endodermal and exodermal root cell. ${ }^{3}$ In general, the concentration of As in terrestrial plant tissues varies between $<0.01$ and $5 \mu \mathrm{g} \mathrm{g}^{-1}$ (dry weight basis). ${ }^{4}$ Plant species can take up As and distribute it within various parts of the same plant, a process sometimes referred to as compartmentalisation. Inorganic As species are often the dominant forms of As in 'terrestrial' plants

${ }^{a}$ School of Geography, Earth and Environmental Sciences, Plymouth University, Plymouth PL4 8AA, UK. E-mail: steve.hill@plymouth.ac.uk

${ }^{b}$ Food Technology Department, College of Agriculture, Salahaddin University-Erbil, Kurdistan, 44002, Iraq and vegetables together with small amounts of organic As species such as dimethyl arsinic acid (DMA) and monomethyl arsonic acid (MMA). ${ }^{5}$ While other organo-As species have also been detected in small quantities, one survey found the inorganic As in the edible tissues of vegetables including carrot, garlic, potato and beetroot ranged from 28 up to $100 \%$ of the total As content. ${ }^{6}$

Despite obvious epigenetic effects from high levels of As upon growth and certain biotransformation processes being noted in biological studies of plants, ${ }^{7,8}$ few studies have covered the cellular level compartmentalisation of As and As species in vegetative/floral systems from root to stem to leaf and flower/ grain together with its DNA-associated arsenic content. This paper reports on studies, down to the cellular (DNA) level, into the processing of arsenic species and their quantification within a selected foodstuff grown within a high arseniccontaining environment.

A preliminary study on measurement of total As in extracted vegetative DNA was first performed on the different 'compartments' (root, stem and leaf) of a series of different edible plants, including the rice plant Oryza sativa; all collected from Kurdistan in Iraq. The final choice of plant was based upon three factors: (i) rice is an important staple food for more than half of the world's population ${ }^{9}$ (ii) different compartments of the rice 
plant samples were contaminated with sufficiently high levels of As, and (iii) arsenic in the DNA extracts were above the LOD of the developed methodology.

The full study included extraction experiments to help identify where vegetative DNA processes interact with these measured As species and compartmentalise them (whether associated with, e.g. weakly bound to DNA, or incorporated, e.g. within DNA, forming part of its structure; potentially replacing phosphate linkages) in order to reduce their toxic effects within the plant. ${ }^{\mathbf{1 0 , 1 1}}$ The instrumental techniques of ICP-OES, ICP-MS and HPLC-ICP-MS were used to measure the total and species concentrations of As and $\mathrm{P}$ in cellular fractions. Levels of phosphorus and phosphate were measured as part of the comparative process after using DNA extraction techniques on the contaminated rice plants.

\section{Experimental}

\subsection{Chemicals and reagents}

Analytical reagent grade chemicals and Milli-Q water $(18 \mathrm{M} \Omega \mathrm{cm})$ were used throughout. Total As standards were prepared from the high purity stock solution $100 \mu \mathrm{g} \mathrm{mL} \mathrm{m}^{-1}$ in $5 \% \mathrm{HNO}_{3}$ (CPI international, USA). Arsenic oxide (InAs ${ }^{\mathrm{III}}$ ), DMA, anhydrous sodium sulfate and Tris were purchased from Sigma-Aldrich (Gillingham, Dorset, UK) and MMA was purchased from Greyhound Chromatography and Allied Chemicals (Birkenhead, Merseyside, UK). The salt $\mathrm{Na}_{2} \mathrm{HAsO}_{4} \cdot 7 \mathrm{H}_{2} \mathrm{O}$ (InAs ${ }^{\mathrm{V}}$ ), In, Ir, sodium chloride, polyvinyl pyrrolidone (PVP), iso amyl alcohol and ammonium dihydrogen orthophosphate (AnalaR grade) were obtained from VWR International (MERCK, Lutterworth, Leicestershire, UK). Hydrogen peroxide $37 \%$ and nitric acid 70\% (Merck, Poole, Dorset, UK) were used. The spinach CRM GBW10015 (Institute of Geophysical and Geochemical Exploration, Langfang, China) was purchased from LGC standards (Middlesex, UK). Cetyltrimethylammonium bromide (CTAB), chloroform, EDTA and $\mathrm{HCl}$ were purchased from Fisher (Loughborough, Leicestershire, UK). Ethanol was obtained from Rathburn (Walkerburn, Scotland).

\subsection{Instrumentation}

An X Series 2 ICP-MS instrument (Thermo Scientific, Hemel Hempstead, UK) was used for both As and P detection. HPLCICP-MS was used for speciation measurements of both As and P. Collision cell technology was used to eliminate the possible argon chloride interference. An iCAP 7400 series ICP-OES instrument (Thermo Scientific) was also used for P determination. The operating conditions employed are described in Table 1. For the ICP-MS analysis, indium and iridium were used as internal standards for all samples at a final concentration of 10 $\mu \mathrm{g} \mathrm{L}^{-1}$. The mass spectrometer was set to sample As ion intensity (peak jumping option) at mass 75 and $\mathrm{P}$ ion intensity at $m / z$ 31. For internal standardisation the signal intensity was sampled at $m / z 115\left({ }^{115} \mathrm{In}^{+}\right)$and $m / z 193\left({ }^{193} \mathrm{Ir}^{+}\right)$.

\subsection{Sample collection and pre-treatment}

The various parts of the rice plant (root, stem, leaf and grain), together with soil samples and irrigation water were collected from the same agriculture sites located in Akre, north west Arbeel in the 'Kurdistan region' of Iraq. The irrigation water samples were collected from the on-site farm well, (where the plant and soil samples were collected) and stored in HDPE sealed tubes. The $\mathrm{pH}$ of the water samples was adjusted with AnalaR grade dilute nitric acid to 2.0 in order to preserve 'total' inorganic-As and total organic-As speciation and prevent losses. Total As was measured using ICP-MS.

All solid samples were placed in sealed, cooled containers at the point of collection. The plant samples were washed with Milli-Q water and stored in a cooled plastic box prior to transportation. All solid samples were frozen at $-40{ }^{\circ} \mathrm{C}$ for $12 \mathrm{~h}$ and then placed in a freeze-drier for $48 \mathrm{~h}$ at $-40{ }^{\circ} \mathrm{C}$. All freeze-dried samples were then ground using an agate pestle and mortar to a fine powder and then sieved using a polypropylene $180 \mu \mathrm{m}$ sieve. The samples were then stored in brown glass bottles and placed in a desiccator in order to avoid exposure to light and moisture until required for analysis.

\subsection{Total 'aqua-regia extractable' As content of the soil samples}

Total aqua regia extractable As in the freeze-dried soil samples and those residues from the later performed BCR fractionation steps, were determined using a modified version of the LGC aqua-regia protocol. ${ }^{12}$ This involved placing sub-samples (approx. $0.50 \mathrm{~g}$ ) of soil material that had passed through a 180 $\mu \mathrm{m}$ polypropylene mesh into Tecator tubes; adding hydrochloric acid $(35 \% ; 8 \mathrm{~mL})$ and nitric acid $(70 \% ; 2 \mathrm{~mL})$ to the samples and allowing them to stand at room temperature for at least one hour so that easily oxidised material could be destroyed. The tubes were then placed in a Tecator digestion block (Digestion system 12, 1009 digester) and heated at $110{ }^{\circ} \mathrm{C}$ for two hours. After cooling, the extracts were transferred quantitatively, without filtering to pre-cleaned $100 \mathrm{~mL}$ capacity volumetric flasks and diluted to volume with deionised water. Three replicates of each sample were prepared together with three replicates of the CRM Loam soil (ERM-CC141; European Commission, Geel, Belgium) for each batch extraction. The CRM was extracted in the same way, while a procedural blank was prepared alongside for analysis, omitting the sample.

\subsection{Total As determination in plant samples}

A Mars Xpress microwave lab station (CEM, USA) with $100 \mathrm{~mL}$ closed Teflon vessels with Teflon covers was used for the acid digestion of samples. Freeze dried samples of plant $(0.25 \mathrm{~g})$ were accurately weighed out in triplicate and placed into separate Teflon reaction vessels. Aliquots of $\mathrm{HNO}_{3}(70 \%, 5 \mathrm{~mL})$ and $\mathrm{H}_{2} \mathrm{O}_{2}$ $(30 \%, 2 \mathrm{~mL})$ were then added to the vessels which were subsequently sealed. All samples were digested for $43 \mathrm{~min}$ at $1600 \mathrm{~W}$. In the first step of the digestion, the temperature was increased to $160{ }^{\circ} \mathrm{C}$ over $15 \mathrm{~min}$ and then held at this temperature for a further $5 \mathrm{~min}$. In the second step of the digestion the temperature was increased from 160 to $200{ }^{\circ} \mathrm{C}$ over $8 \mathrm{~min}$ and then held at this temperature for a further $15 \mathrm{~min}$. After digestion, the Teflon reaction vessels were allowed to stand at room temperature until cool. Once the digestion was 
Table 1 ICP-MS and ICP-OES operating conditions used for the determination of As and P in samples including As and P in DNA extracts of plant sample

ICP-MS

Dwell time (ms)

ICP-OES

Phosphorus

Gas flows/L $\min ^{-1}$
X Series 2 (Thermo Scientific)

Peristaltic pump speed/mL $\mathrm{min}^{-1}$

Nebulizer type

Spray chamber

RF forward power/W

Coolant

Auxiliary

Nebulizer

Collision cell gas flow $\left(\mathrm{mL} \mathrm{min}^{-1}\right) 7 \% \mathrm{H}_{2}$ in $\mathrm{He}$

ICP-MS

HPLC-ICP-MS

\section{2}

V-groove

Sturman-Masters 1400

13

0.75

1.0

3.6

10

100

$\begin{array}{ll} & \text { iCAP } 7400 \text { (Thermo Scientific) } \\ & \text { Peristaltic pump speed } \mathrm{mL} \mathrm{min} \mathrm{m}^{-1} \\ & \text { Nebuliser type } \\ & \text { Spray chamber } \\ & \text { Exposure time }(\mathrm{s}) \\ & \text { Radio frequency power }(\mathrm{W}) \\ & \text { Viewing height }(\mathrm{mm}) \\ \text { Phosphorus } & \text { Wavelength }(\mathrm{nm}) \\ \text { Gas flows/L } \mathrm{min}^{-1} & \text { Coolant } \\ & \text { Auxiliary } \\ & \text { Nebulizer }\end{array}$

1.1 Burgener (MiraMist) Cyclone

2 1150 12 177.4 12

0.5

0.5 completed, the totally digested samples were transferred quantitatively into volumetric flasks and made up to volume with $2 \%(\mathrm{v} / \mathrm{v}) \mathrm{HNO}_{3}$, prepared with Milli-Q water. The samples and standards were spiked with the internal standards (In and Ir) to give the final concentration of $10 \mu \mathrm{g} \mathrm{L} \mathrm{L}^{-1}$. The certified reference material GBW10015 (spinach) was used to validate the total As determination in different parts of the rice plant. Procedural blanks were prepared for measurement, as part of the correction process.

\subsection{Plant 'available' arsenic; estimation using the 'sequential extraction method' for As and concomitant elements in soil}

The determination and distribution of the plant-available content of soil is important in terms of plant nutrition, deficiency and toxicity evaluation. This includes major nutrients $(\mathrm{N}$, $\mathrm{P}, \mathrm{K}$ ) as well as essential trace elements and potentially toxic elements. ${ }^{13}$ The BCR (now the Standards, Measurements and Testing Programme; SM\&T) has developed a three stage, sequential extraction protocol and according to this extraction protocol metals can be divided into acid soluble/exchangeable, reducible and oxidisable fractions. The three steps involved are:

Step 1: Extraction of $1.0 \mathrm{~g}$ soil by shaking for 16 hours in $40 \mathrm{~mL}$ of $0.11 \mathrm{M}$ acetic acid solution $\left(22 \pm 5{ }^{\circ} \mathrm{C}\right)$. Solids are separated from the extract by centrifugation. The acid extract is analysed and the washed solid is retained for step 2 .

Step 2: The retained solid from step 1 is extracted by shaking for 16 hours in $40 \mathrm{~mL} 0.5 \mathrm{M}$ hydroxylamine hydrochloride $(22 \pm$ $5{ }^{\circ} \mathrm{C}$ ). Solids are separated from the extract by centrifugation. The extract is analysed and the washed solid is retained for step 3.
Step 3: The retained solid from step 2 is extracted by carefully shaking with two $10 \mathrm{~mL}$ aliquots $8.8 \mathrm{M}$ hydrogen peroxide (adjusted to $\mathrm{pH} 2$ ) using a two stage temperature controlled regime (up to $85 \pm 2{ }^{\circ} \mathrm{C}$ ), reducing the liquid volume and then shaking this for a further 16 hours in $50 \mathrm{~mL}$ of $1.0 \mathrm{M}$ ammonium acetate solution $\left(22 \pm 5{ }^{\circ} \mathrm{C}\right)$ adjusted to $\mathrm{pH} 2$. Solids are separated from the extract by centrifugation. The extract is analysed and the washed solid is retained for residue analysis.

This modified BCR sequential extraction (three-step) procedure for the determination of extractable trace metal contents ${ }^{\mathbf{1 3}}$ was employed in the estimation of the 'Plant-Available' As and concomitant elements from the crop soil.

\subsection{Phosphoric acid extraction for As speciation in soil}

Soil samples, (approx. $0.5 \mathrm{~g}$ ), were accurately weighed into a microwave vessel tube, and $25 \mathrm{~mL}$ of a mixture of $1.0 \mathrm{~mol} \mathrm{~L}^{-1}$ orthophosphoric acid and $0.1 \mathrm{~mol} \mathrm{~L}^{-1}$ ascorbic acid was then added. Ascorbic acid was added to inhibit any oxidation reaction of As species. ${ }^{\mathbf{1 4}}$ Samples were then extracted in a Mars Xpress microwave lab station (CEM, USA). The vessels were subjected to microwave extraction procedures under controlled conditions at $80{ }^{\circ} \mathrm{C}$ for $20 \mathrm{~min} .{ }^{15}$ After cooling, the samples were quantitatively transferred to a $50 \mathrm{~mL}$ capacity centrifuge tube. The same extraction procedure was repeated for all the samples. A procedural blank was prepared in similar fashion, but omitting the sample. The extracted samples were then centrifuged at $2000 \mathrm{rpm}$ (Sanyo Centaur 2, UK) for a period of 20 minutes and the supernatant decanted into pre-cleaned $100 \mathrm{~mL}$ capacity volumetric flasks. The samples were then diluted to volume using Milli-Q water. 


\subsection{Extraction procedures for the speciation of As in vegetable plants}

This method was adopted from the work of Sun et al. ${ }^{16}$ A $0.50 \mathrm{~g}$ sample was accurately weighed into a $50 \mathrm{~mL}$ polypropylene extraction tube and $25 \mathrm{~mL}$ of $1 \%$ nitric acid was added and left overnight. Samples were then extracted using a microwave oven. In the first step of the extraction, the temperature was increased up to $55{ }^{\circ} \mathrm{C}$ over $5 \mathrm{~min}$ and then held at this temperature for a further $10 \mathrm{~min}$. In the second step of the extraction, the temperature was increased from $55{ }^{\circ} \mathrm{C}$ to $75{ }^{\circ} \mathrm{C}$ over 5 min and then held for a further $10 \mathrm{~min}$. Finally, the temperature was raised to $95{ }^{\circ} \mathrm{C}$ and held at this temperature for $30 \mathrm{~min}$. Samples were then cooled to room temperature and centrifuged at $3000 \mathrm{rpm}$ for $30 \mathrm{~min}$. The supernatant was filtered through a $0.45 \mu \mathrm{m}$ filter (Millipore) and kept at $4{ }^{\circ} \mathrm{C}$ until analysis. Procedural blanks were prepared for measurement, as part of the correction process.

\subsection{Chromatographic conditions used in the HPLC-ICP-MS coupled technique for the determination of (i) As species in soil and plant extracts and (ii) As and $P$ in extracted DNA}

Chromatographic separations were carried out using a Jasco chromatographic pump (Tokyo, Japan) with a $250 \times 4.6 \mathrm{~mm}$ column packed with $10 \mu \mathrm{m}$ particle size Hamilton PRP-X100 anion exchange resin. A $50 \times 4.6 \mathrm{~mm}$ guard column packed with the same material was used to protect the column. A Rheodyne 7152 injection valve (Rheodyne, Cotati, CA, USA) employing a six-way injection port was used. The interfacing between HPLC and ICP-MS was carried out using Teflon capillary tubing ( $0.5 \mathrm{~mm}$ i.d.) which connected the column outlet directly with the inlet to the nebulizer. An Oakton pH meter (Eutech Instruments, Singapore) was used to take $\mathrm{pH}$ readings. Two mobile phase systems were employed for HPLC-ICP-MS speciation and 'fractionation' measurements: (i) a phosphate buffer $(20 \mathrm{mM}$ ammonium dihydrogen orthophosphate in $1 \%$ $\mathrm{CH}_{3} \mathrm{OH}$ adjusted to $\mathrm{pH} 6.0$ with ammonia) for arsenic and (ii) $6.5 \mathrm{mM}$ sodium sulfate $(\mathrm{pH} 10.2-10.5)$ in $5 \% \mathrm{CH}_{3} \mathrm{OH}$ for the phosphorus/phosphate system and the comparative As fraction in DNA extracts. The eluent flow rate used was $1.1 \mathrm{~mL} \mathrm{~min}{ }^{-1}$. The injection volume used for both chromatographic measurements was $20 \mu \mathrm{L}$. The ion intensities at $m / z 75$ and 31 were monitored continually during the analysis and quantification was performed using peak area against known standards.

\subsection{Plant genomic DNA extraction using CTAB}

A cetyltrimethylammonium bromide (CTAB) protocol was adopted for the isolation of high-quality genomic DNA from all plant samples. ${ }^{17}$ The CTAB buffer was prepared using $2.0 \mathrm{~g}$ of CTAB, $10 \mathrm{~mL} 1 \mathrm{M}$ Tris (pH 8.0), $4 \mathrm{~mL}$ of $0.5 \mathrm{M}$ EDTA (pH 8), $28 \mathrm{~mL} 5 \mathrm{M} \mathrm{NaCl}, 40.0 \mathrm{~mL} \mathrm{H}_{2} \mathrm{O}$ and $1 \mathrm{~g}$ polyvinyl pyrrolidone (vinylpyrrolidine homopolymer) $M_{\mathrm{w}} 40000$ (PVP). The final solution was adjusted to $\mathrm{pH} 5.0$ with $\mathrm{HCl}$ and made up to $100 \mathrm{~mL}$ with Milli-Q water. Freeze-dried 'plant tissue' $0.5 \mathrm{~g}$ was weighed into a $15 \mathrm{~mL}$ plastic centrifuge tube and $5 \mathrm{~mL}$ of
CTAB was added. The $\mathrm{CTAB} /$ plant tissue was incubated for about $15 \mathrm{~min}$ at $55{ }^{\circ} \mathrm{C}$ in a water bath. After incubation, the $\mathrm{CTAB} /$ plant extract mixture was spun at $3500 \mathrm{rpm}$ for $15 \mathrm{~min}$ to spin down the cell debris. To each tube $2 \mathrm{~mL}$ of a chloroform : iso amyl alcohol mixture (24:1) was added and the contents mixed by inversion. After mixing, the tubes were spun at $3500 \mathrm{rpm}$ for $5 \mathrm{~min}$. The upper aqueous phase (which contains the required DNA) was transferred to a clean plastic centrifuge tube. To each tube $250 \mu \mathrm{L}$ of $7.5 \mathrm{M}$ ammonium acetate followed by $2.5 \mathrm{~mL}$ of ice cold absolute ethanol was added. The tubes were inverted slowly several times to precipitate the DNA. Generally DNA can be seen to precipitate out of solution. Alternatively the tubes can be placed for $1 \mathrm{~h}$ at $-20{ }^{\circ} \mathrm{C}$ after the addition of ethanol to help precipitate the DNA. The precipitated DNA was transferred into clean plastic centrifuge tubes. The precipitated DNA was considered to be a 'crude DNA' extract at this stage and the total As in this crude DNA can be measured, without washing, using ICP-MS after digestion with nitric acid. The total As in a fully processed DNA pellet was determined using ICP-MS after washing with ice cold $70 \%$ ethanol. To wash the primary extractable DNA, the precipitated DNA was transferred into plastic centrifuge tubes containing $0.5 \mathrm{~mL}$ of ice cold $70 \%$ ethanol and slowly inverted. The precipitate was isolated by spinning the tube at $3500 \mathrm{rpm}$ for $1 \mathrm{~min}$ to form a pellet. The supernatant was removed; the DNA pellet was washed by adding two further changes of ice cold $70 \%$ ethanol. The DNA washed pellets were then either (i) digested in nitric acid for total As or (ii) dissolved in $10 \mathrm{mM}$ Tris- $\mathrm{HCl}(\mathrm{pH} 8) ; 1 \mathrm{mM}$ EDTA (pH 8) ${ }^{\mathbf{1 8}}$ for 'fractionation' analysis using HPLC-ICP-MS. The procedure is shown in Fig. 1.

\section{Results and discussion}

\subsection{Limits of detection}

Detection limits for As species were calculated from the analysis of six replicate determinations of the 'procedural' blank samples using the following equation: $\mathrm{LOD}=3 \times \mathrm{SD}$; where $\mathrm{SD}$ is the standard deviation of the procedural blank sample values in concentration units.

Table 2 shows the limit of detection of six measurements of the sample blank $\left(1.0 \mathrm{~mol} \mathrm{~L}^{-1}\right.$ orthophosphoric acid and $0.1 \mathrm{~mol} \mathrm{~L}^{-1}$ ascorbic acid, $1 \% \mathrm{HNO}_{3}$ and $10 \mathrm{mM}$ Tris buffer $\mathrm{pH} 8$ and $1 \mathrm{mM}$ EDTA pH 8 was used to extract As species from soil, from the different compartments of plant itself and the DNA extract of plants, respectively).

\subsection{Total and extractable As determinations}

(i) Results of CRM analyses for total and extractable As. To validate the applied procedures, both total and extractable As was determined in different certified reference materials for the different sample matrices. The analytical validity for As was based on the use of CRMs, GBW 10015 spinach, loam soil (ERMCC141) and BCR 701-lake sediment. These reference materials were selected to represent plant and soil samples. Good recoveries were found for total As in the spinach and aqua-regia 


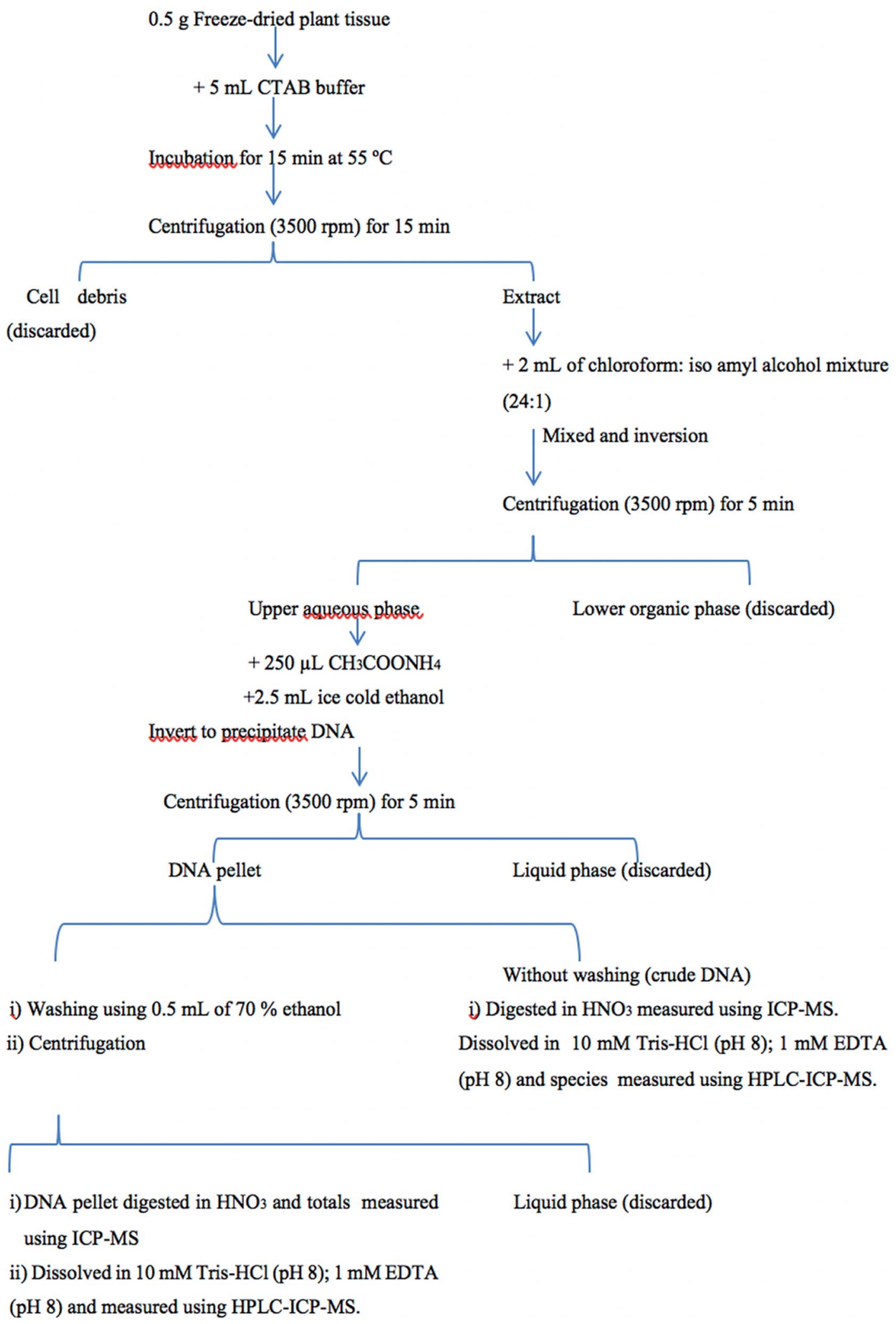

Fig. 1 Schematic diagram for extraction of DNA from plant material using CTAB buffer for analytical measurement of As and As species.

extractable As in the loam soil, with values of 108 and $98 \%$ of the certificate value respectively. These results for the As content in all CRMs are shown in Table 3. (ii) Crop soil sample. The different concentrations of As in different parts of the rice plant clearly has implications regarding the potential toxicity of As in this food crop if grown 
Table 2 Detection limits ( $3 \times$ standard deviation of the sample blank) determined during analysis of As species in soil, in plant extracts and in DNA extracts using ICP-MS and HPLC-ICP-MS; all values are in $\mu \mathrm{g} \mathrm{g}^{-1}$

\begin{tabular}{|c|c|c|c|c|}
\hline Arsenic species & InAs ${ }^{I I I}$ & MMA & DMA & $\operatorname{InAs} \mathrm{v}^{\mathrm{V}}$ \\
\hline Phosphoric acid extraction & 0.080 & 0.084 & 0.119 & 0.09 \\
\hline $1 \% \mathrm{HNO}_{3}$ & 0.006 & 0.011 & 0.014 & 0.012 \\
\hline $10 \mathrm{mM}$ Tris buffer and $1 \mathrm{mM}$ EDTA, pH 8 & 0.004 & - & - & 0.006 \\
\hline
\end{tabular}

Table 3 Certified reference material analyses for total and extractable As; all experimental values are given in $\mu \mathrm{g} \mathrm{g}{ }^{-1}$, mean $^{\prime} \mathrm{standard}$ deviation $(n=3)$

\begin{tabular}{|c|c|c|c|c|}
\hline Loam soil (ERM-CC141) & Soil & ${ }^{a} 7.5 \pm 1.4$ & ${ }^{a} 7.33 \pm 0.42$ & 98 \\
\hline GBW10015 spinach & Plant & $0.23 \pm 0.03$ & $0.249 \pm 0.008$ & 108 \\
\hline
\end{tabular}

in areas with available As in the soil. To further investigate the As uptake by rice, the 'extractable' concentration of As was also measured in soils collected from the same points as the plants. The modified LGC extraction protocol was applied to measure the As content (aqua regia extractable content) in the soil and the concentration of total aqua regia extractable As in the soil samples was determined to be $2.88 \mu \mathrm{g} \mathrm{g}^{-1}$ (Table 4).

(iii) Irrigation water samples. The total concentration of As in the irrigation water sampled was $0.58 \mu \mathrm{g} \mathrm{L} \mathrm{L}^{-1}$ (Table 4) which is significantly below the recommended limiting value for As in drinking water by the WHO $\left(10 \mu \mathrm{g} \mathrm{L}^{-1}\right) .{ }^{19,20}$ Since the concentration of As in water is very low and lies near the limit of detection for species measured using HPLC-ICP-MS, further analysis on the water was not performed. At this level, the irrigation water was not felt to be a significant reservoir in terms of concentration of As to the plant. However, it could contribute significantly over time by acting as a facilitator at the root surface and soil interface, assisting As mobility on a continuous basis.

Arsenic was found in the grain $\left(1.02 \mu \mathrm{g} \mathrm{g}^{-1}\right)$. This is consistent with previous findings that As concentrates in roots of rice more than stem, leaf and grain of the same plant. ${ }^{1,9}$ To validate the applied procedure, As was determined in the certified reference material GBW10015 (spinach) which demonstrated full recovery.

Table 4 The concentration of total As in plant samples and extractable

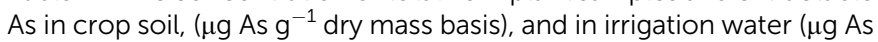
$\left.\mathrm{L}^{-1}\right)$ mean $\pm \mathrm{SD}(n=3)$

\begin{tabular}{ll}
\hline Matrix & Total As $\left(\mu \mathrm{gs} \mathrm{g}^{-1}\right)$ \\
\hline Crop soil & $2.88 \pm 0.05$ \\
Rice - root & $8.28 \pm 0.539$ \\
Rice - stem & $4.00 \pm 0.264$ \\
Rice - leaf & $2.93 \pm 0.054$ \\
Rice - grain & $1.02 \pm 0.089$ \\
Water & $0.58 \pm 0.02 \mu \mathrm{g} \mathrm{L}^{-1}$
\end{tabular}

\subsection{Arsenic speciation analysis}

(i)Soil sample. Loam soil CRM was used to validate the phosphoric acid extraction procedure of As species from the crop soil that the rice plant was cultivated in. The results showed good extraction efficiency (96\%) of As in extracts compared with the certified value and $98 \%$ with respect to the aqua-regia extractable As content in loam soil, Table 3. The As extraction efficiency from the sample soil using phosphoric acid compared with the aqua regia 'total' was 93\% (Table 5). The major species found in the soil was InAs ${ }^{\mathrm{V}}\left(2.31 \mu \mathrm{g} \mathrm{g}^{-1}\right)$ with smaller quantities of InAs ${ }^{\text {III }}$ $\left(0.37 \mu \mathrm{g} \mathrm{g}^{-1}\right)$ present. The stability of the As species (InAs ${ }^{\text {III }}$ and InAs ${ }^{\mathrm{V}}$ ) under the applied extraction conditions was also measured by spiking those As species standards into the loam soil reference material. The results demonstrated good stability for both species after the extraction with a variability of only $2 \%$ for both species when considering the analytical uncertainty. This high stability may be attributed to adding ascorbic acid to the extractant media to prevent oxidation of As species. ${ }^{21}$ The different As species concentrations found in the soil under study are presented in Table 5 .

(ii) Plant sample. The inorganic As species are generally the more toxic forms to humans ${ }^{22}$ and predominate in plants ${ }^{23,24}$ including a number of different crops and vegetables. ${ }^{\mathbf{9 , 2 5}}$ The same species have been found to be predominant both in the roots and the stems. ${ }^{23}$

The different 'compartments' were analysed for their extracted As species using the coupled technique anion-HPLCICP-MS and was successfully employed to separate As species with $\mathrm{NH}_{4} \mathrm{H}_{2} \mathrm{PO}_{4}$ as a mobile phase. Example-chromatograms of the standards and rice root-extract are shown in Fig. 2 and 3, respectively. A chromatogram of the extracts from a root of the rice plant using the same anionic-exchange system is shown in Fig. 3. The values for As speciation in the rice sample are presented in Table 5.

The extraction efficiencies for As ranged between 97\% and $100 \%$, as shown in Table 5. Arsenic accumulation was greater in the roots $\left(8.28 \mu \mathrm{g} \mathrm{g}^{-1}\right)$ compared with other parts of the rice 


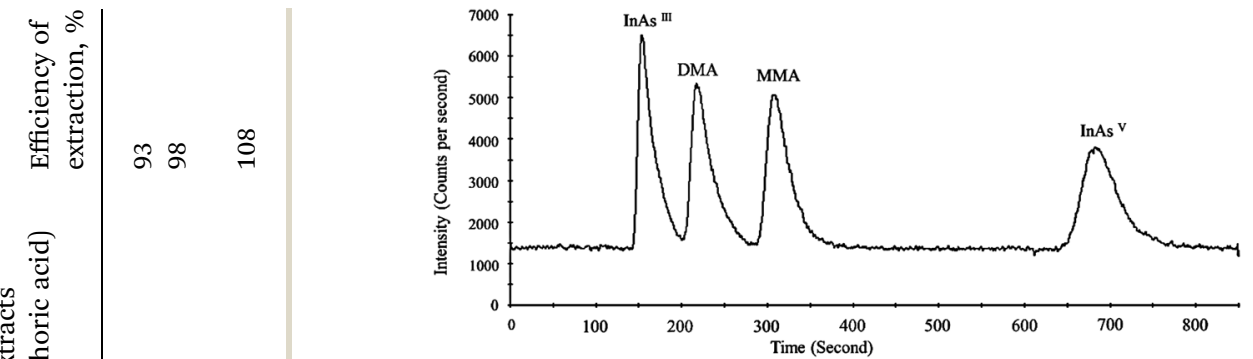

Fig. 2 Chromatogram of four As species standards in aqueous solution. InAs ${ }^{\prime \prime \prime}, \mathrm{DMA}, \mathrm{MMA}$ and $\ln A s^{\vee} 50 \mu \mathrm{g} \mathrm{L}^{-1} \mathrm{As}$, employing a Hamilton PRP-X100 anion-exchange HPLC column using the conditions described in Table 1 and section 2.9.

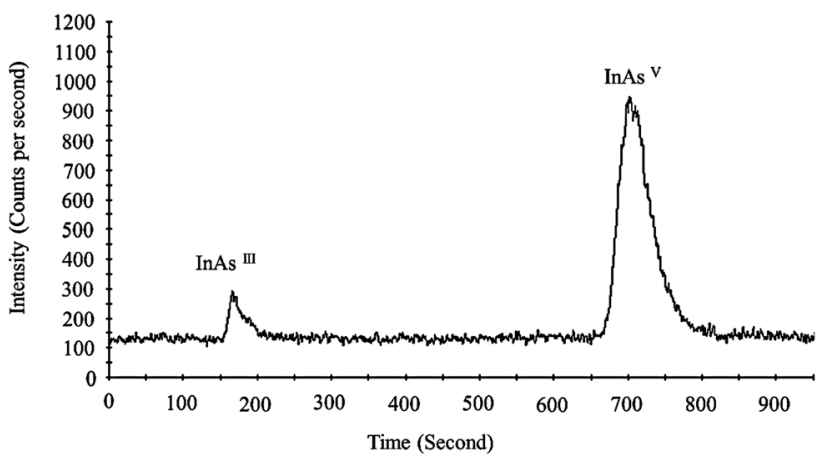

Fig. 3 Chromatogram showing the As species in the extracts of the root of the rice plant using anionic-exchange HPLC-ICP-MS and using conditions identified in Table 1.

plant - in fact eight times higher than the concentration of As in the rice grain itself. The concentration of total As decreased gradually from the root to the grain of the rice plant. This reduction in the total amount of As may reflect the eliminating metabolic pathway of As in rice plants.

The InAs ${ }^{\mathrm{III}}$ and InAs ${ }^{\mathrm{V}}$ were the major species found in the root, stem, leaf and grain compartments of the rice plant. The organic As species, MMA and DMA, were below their limit of detection for the same compartments of the rice plant (root, stem, leaf and grain; Fig. 4). InAs ${ }^{\mathrm{V}}$ was the dominant species in each part of the rice plant (Fig. 4 and Table 5). It is interesting to note that the speciation study on the Akre soil showed only inorganic As (total extractable, $2.88 \mu \mathrm{g} \mathrm{g}^{-1} ; 86 \%$ InAs $^{\mathrm{V}}$ : $14 \%$ InAs ${ }^{\text {III }}$ ) present with this ratio being approximately maintained in each 'compartment' of the rice plant; root, stem, leaf and grain, even with the total As decreasing from root to grain (Fig. 4). The As in the rice grain $\left(1.02 \pm 0.09 \mu \mathrm{g} \mathrm{g}^{-1}\right)$ was five times higher than the 'global range' concentration of As in rice. This could possibly cause a risk to humans by consumption of this rice. According to Zavala and Duxbury ${ }^{26}$ the global "normal" range for As in rice grain is 0.08 to $0.20 \mu \mathrm{g} \mathrm{g}^{-1}$.

\subsection{Plant 'available' As}

A standard BCR protocol was applied to estimate plant 'available' As in the soil used to cultivate the rice plant samples. The 

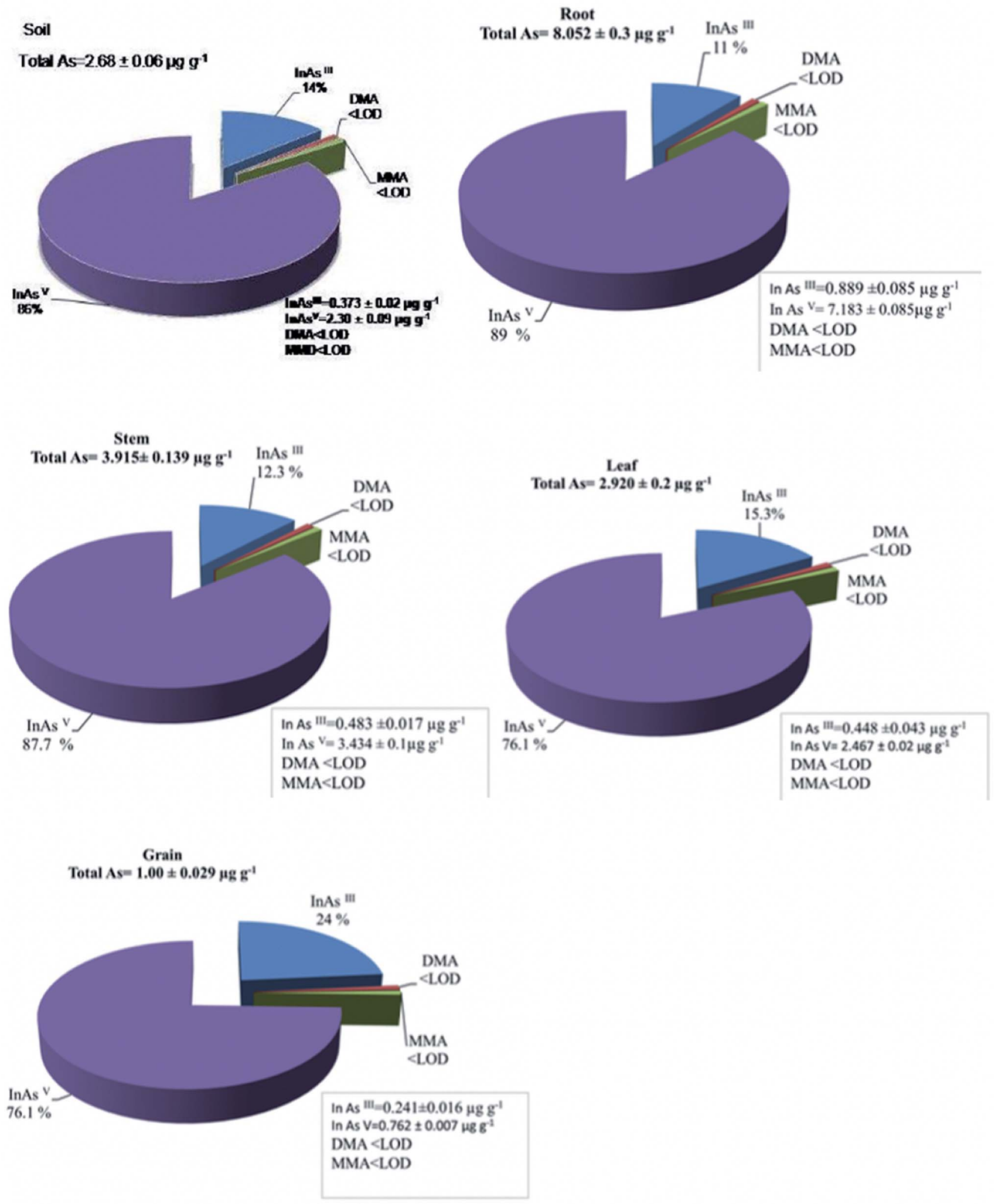

Fig. 4 Total arsenic and speciation in the soil, root, stem, leaf and grain samples of the rice plant.

certified reference material BCR 701 was used to validate the sequential extraction procedure, based upon five metals, $\mathrm{Cd}, \mathrm{Cr}$, $\mathrm{Cu}, \mathrm{Ni}$ and $\mathrm{Zn}$, as As has not been certified in BCR 701. The extractable contents from each step of the standard reference material used are presented in Table 6 and in most cases recoveries range between 90 and 108\%. Alvarez and Carrillo ${ }^{27}$ 
Table 6 Results of analysis of CRM (BCR 701-lake sediment) and soil under study using the BCR-sequential extraction; mean \pm standard deviation $(n=3)$

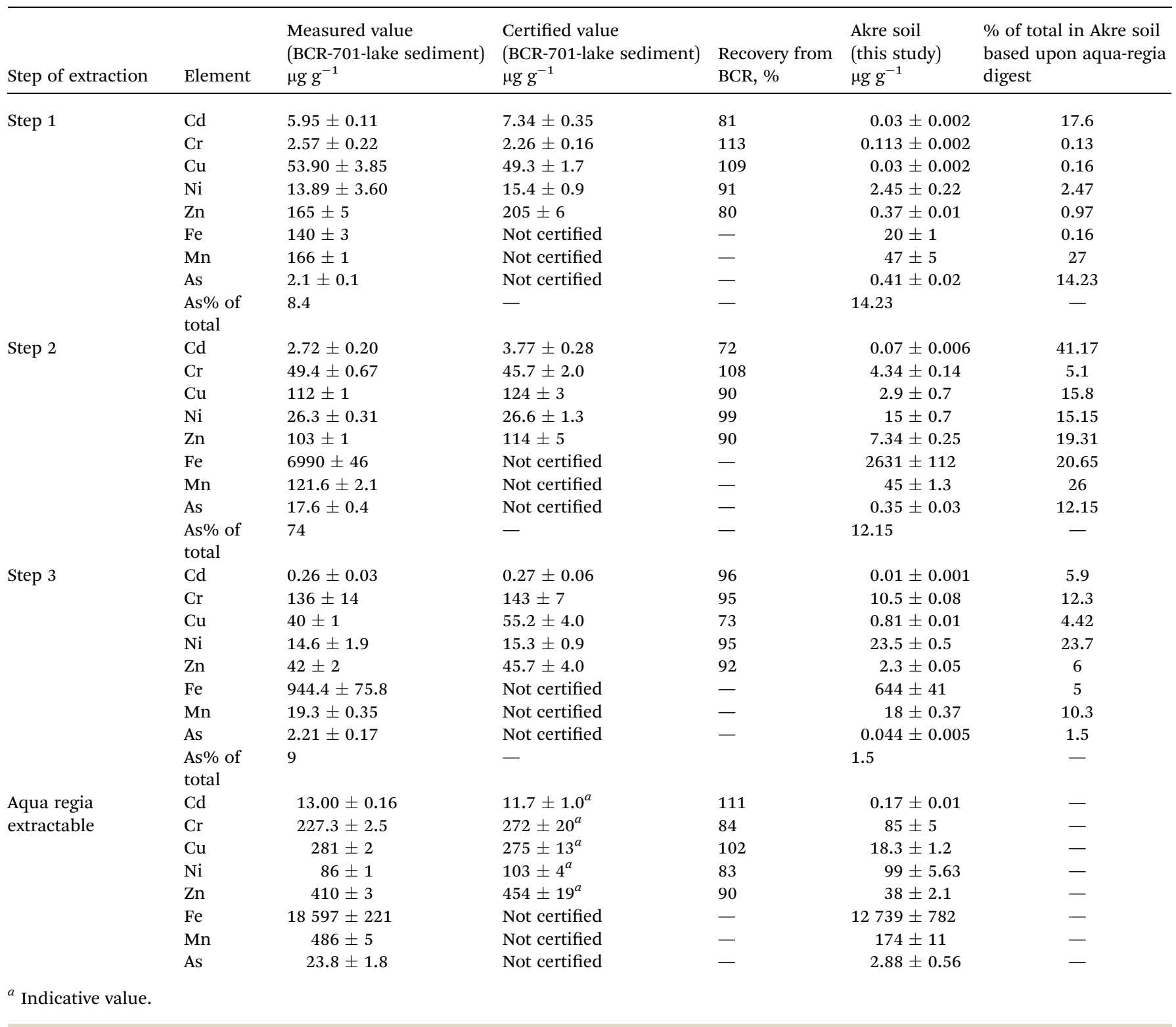

measured the As concentration in BCR 701 using the sequential extraction procedure for steps 1 and 2, giving step one as $2.1 \pm$ $0.1 \mu \mathrm{g} \mathrm{As} \mathrm{g}{ }^{-1}$ (mean $\pm \mathrm{SD}$ ) and step two as $21.2 \pm 1.1 \mu \mathrm{g} \mathrm{As} \mathrm{g}^{-1}$ (mean $\pm \mathrm{SD}$ ). The concentrations of As found in our study in steps 1 and 2 were $2.1 \pm 0.1 \mu \mathrm{g} \mathrm{As} \mathrm{g}^{-1}$ (mean $\pm \mathrm{SD}$ ) and $17.6 \pm$

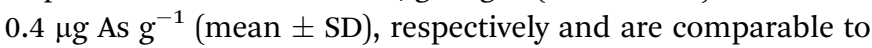
Alvarez and Carrillo's study. ${ }^{27}$

The total element contents is insufficient to evaluate the mobility of trace elements, their availability and their ecotoxicity to plants, whereas the determination of specific chemical forms or types of binding are useful tools for this purpose. ${ }^{28}$ The maximum amount of As which could potentially be mobilised in the soil under study (aqua-regia extractable) was $2.88 \mu \mathrm{g}$ $\mathrm{g}^{-1}$ (Table 6). Overall, only some $27.8 \%$ of As in the analysed Akre soil was mobilized using the whole BCR procedure. Arsenic in the studied soil was found to be bound mainly within the residual fraction $\left(68.4 \%, 1.97 \mu \mathrm{g} \mathrm{g}^{-1}\right.$ from digestion). Step 1 may be considered to provide good correlation with plant uptake ${ }^{29}$ and some $14.2 \%$ of the As $\left(0.41 \mu \mathrm{g} \mathrm{g}^{-1}\right)$ was present in this easily acid-soluble extractable fraction. The levels of As encountered within the root system were over 20 times this available quantity on a mass-for-mass basis. The 'reducible' and 'organic materials and sulfides' fractions extracted from the soil under study gave $12.1 \%$ As $\left(0.31 \mu \mathrm{g} \mathrm{g}^{-1}\right)$ and only $1.5 \%\left(0.044 \mu \mathrm{g} \mathrm{g}^{-1}\right)$, which are considered less available. This is in contrast to the BCR-701 soil, as shown in Table 6. Table 6 also places on record the extraction efficiencies for the major metallic species $\mathrm{Cd}, \mathrm{Cr}, \mathrm{Cu}$, $\mathrm{Ni}, \mathrm{Zn}, \mathrm{Fe}$ and Mn present in the Akre soil using the same 3 step BCR sequential extraction procedure. 


\subsection{Study for total As levels in DNA extracts from plant samples}

3.5.1 Method development for the study of As with extracted DNA. The chemical form of 'arsenic' within the DNA from the selected rice plant was of particular interest; because of the level encountered in the plant and because of the possibility of inorganic As becoming incorporated into the DNA structure replacing phosphate linkages. However, the levels of the total As in the DNA from the rice plant are low compared with the levels of InAs ${ }^{\mathrm{III}}$ and InAs $^{\mathrm{V}}$ from the plant. Table 7 shows the total As in DNA from each compartment (root, stem and leaf) of the rice plant together with the concentration of As species for the rice plant as a whole.

It is important to note that the levels of total As in the DNA from the rice root are considerably greater than the individual organic As levels from DMA and MMA found in that compartment of the plant. The suggestion that the As associated with DNA from the rice plant root includes an inorganic form would however require further studies to confirm. A 'fractionation' methodology for As in the extracted DNA was therefore developed, and included using the different compartments of the rice plant. This was in order to help identify whether As is just associated (weakly bound) or actually incorporated within the DNA framework itself.

3.5.2 Analysis of cellular DNA extracts from the rice plant for arsenic and phosphorus content. A CTAB buffer was used to extract DNA from the selected rice plant. The extracted DNA was digested in $\mathrm{HNO}_{3}$ in order to measure the total As and $\mathrm{P}$ content using ICP-MS. To partially validate the method, procedural blanks were performed with each extraction step as there is no appropriate CRM for As in extracted nucleic acid. The purity of the standard phosphate used in its speciation studies was checked against the phosphorus standard calibration using ICP-OES (conditions shown in Table 1). The ICP-OES instrument was also used to measure the total P content of the DNA extracts in each sample to further verify the concentration of phosphate data obtained using HPLC-ICP-MS. The development of the extraction methodology to identify whether As is associated with, or integrated within the vegetative DNA (part of structure potentially replacing phosphate linkage) in different parts of rice plant was undertaken.

3.5.2.1 Total As in rice DNA. The extraction conditions shown in Fig. 1 were used to extract DNA from the different compartments of the rice plant sample. Total As in the extracted DNA (without and with $3 \times$ washing using $70 \%$ ethanol) was then measured. The results are shown in Tables 7 and 8. They show that the concentrations of the total As in the extracts of DNA increased with increasing total As content in different compartments of the plant itself. The highest concentration of As in the extracted DNA from the rice plant was found in the root. As the total concentration of As in different parts of the rice plant decreased from the root to the leaf the concentration of total As in the extracted DNA decreased in the same order (root $>$ stem $>$ leaf).

3.5.2.2 Effect of washing DNA extracts on As content. From the root of the rice plant, the concentration of total As in extracted DNA was $0.199 \mu \mathrm{g} \mathrm{g}^{-1}$ (Table 7). This was without washing the DNA pellet. When the DNA pellet was washed thrice with $70 \%$ ethanol the concentration of the total As in the extracted DNA decreased to $0.188 \mu \mathrm{g} \mathrm{g}^{-1}$. This result shows how ' $70 \%$ ethanol' washings can remove As that is weakly associated with the DNA and further washing did not change this result. This is only approximately $5.5 \%$ of the total As associated with the DNA, therefore washing $3 \times$ with $70 \%$ ethanol was used throughout the rest of the experiments.

3.5.2.3 'Fractionation' studies of As and $P$ in rice DNA. In order to investigate the relationship between certain forms of As and cellular fractions, including DNA, from the rice plant grown in an elevated arsenic-bearing environment, HPLC-ICP-MS was used. However, the mobile phase used in previous speciation work had been based upon an $\mathrm{NH}_{4} \mathrm{H}_{2} \mathrm{PO}_{4}$ buffer. This required changing if $\mathrm{P}$ was also to be measured. An alternative system used previously (and successfully) was sodium sulfate as the competitive species in anion exchange chromatography. Sodium sulfate was therefore used as the mobile phase to separate both InAs ${ }^{\mathrm{III}}$, InAs ${ }^{\mathrm{V}}$ (Fig. 5 using inorganic As standards) and phosphate (Fig. 7). It is noted that DMA and MMA were below the LOD $\left(0.011\right.$ and $0.014 \mu \mathrm{g} \mathrm{g}^{-1}$, for DMA and MMA respectively) in the different compartments of rice plant under study.

3.5.2.4 Dissolution of DNA extracts for 'fractionation' studies. Pellets of DNA from the rice plant compartments, root, stem and leaf, were completely dissolved using $10 \mathrm{mM}$ Tris and $1 \mathrm{mM}$ EDTA at pH 8 in order to release both the As that was present and the phosphate into solution. Spiking experiments (at $18 \mu \mathrm{g}$ $\mathrm{L}^{-1}$ ) were conducted to check the stability of the As species using this buffer solution. The recovery of both InAs ${ }^{\mathrm{III}}$ and InAs $\mathrm{V}$ were $102 \%$ and $101 \%$, respectively. It is thought that this is the first trial on the determination of As fractionation in whole DNA extracts from plants. When the extracts of DNA from the root of the rice plant were injected and eluted through the anion-

Table 7 Concentration of As species in the rice plant and the total As in DNA extracts of the different compartments of the rice plant; all values are in $\mu \mathrm{g} \mathrm{g}^{-1}$

\begin{tabular}{|c|c|c|c|c|c|c|}
\hline Sample & InAs ${ }^{\text {III }}$ in plant & InAs ${ }^{\mathrm{V}}$ in plant & DMA & MMA & $\begin{array}{l}\text { Total As in DNA } \\
\text { without washing }\end{array}$ & $\begin{array}{l}\text { Total As in DNA washing } \\
\text { with } 70 \% \text { ethanol }^{a}\end{array}$ \\
\hline Rice-root & $0.889 \pm 0.014$ & $7.183 \pm 0.085$ & $<0.011$ & $<0.014$ & $0.199 \pm 0.005$ & $0.188 \pm 0.014$ \\
\hline Rice-leaf & $0.448 \pm 0.043$ & $2.467 \pm 0.02$ & $<0.011$ & $<0.014$ & $0.048 \pm 0.005$ & $0.036 \pm 0.001$ \\
\hline
\end{tabular}

${ }^{a}$ For information and for later comparison, as in Table 8. 


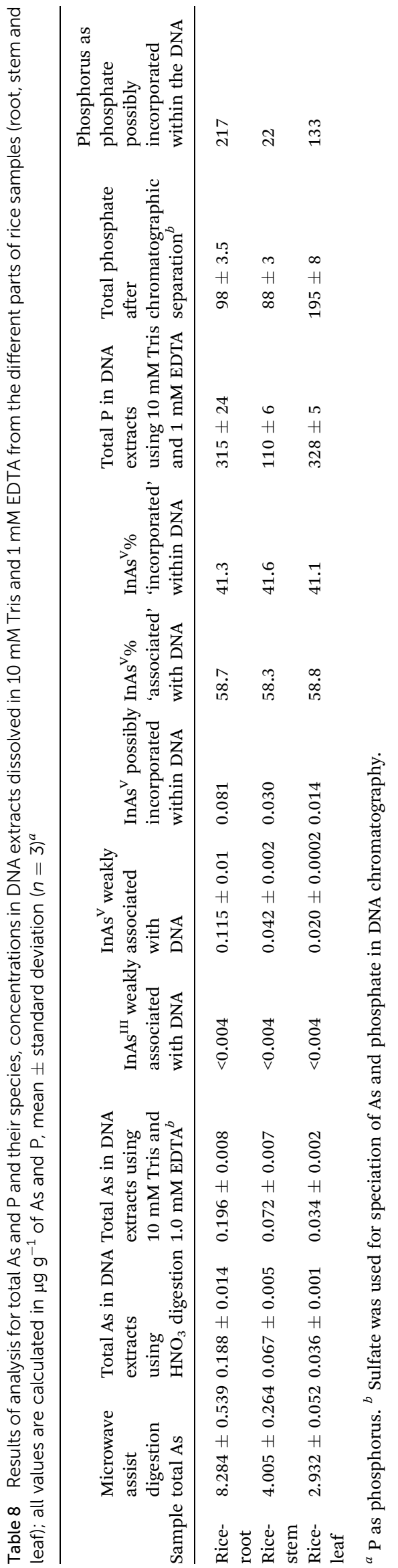

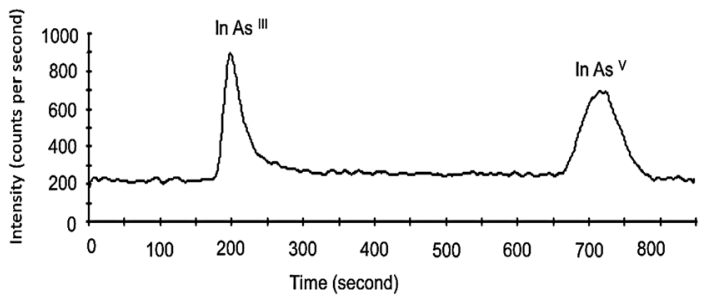

Fig. 5 Chromatogram of $\operatorname{InA} s^{\prime \prime \prime}$ and $\operatorname{In} A s^{\vee}$ in aqueous solution. InAs $s^{\prime \prime \prime}$ and $\ln A s^{\vee} 50 \mu \mathrm{g} \mathrm{L}^{-1}$ As, employing a Hamilton PRP-X100 anionexchange HPLC column using $6.5 \mathrm{mM}$ sodium sulfate as a mobile phase at $\mathrm{pH} 10.2$.

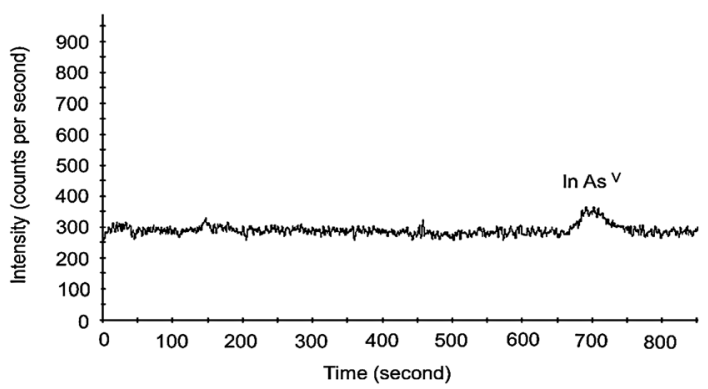

Fig. 6 Chromatogram of As species in DNA extracts from the rice root sample employing a Hamilton PRP-X100 anion-exchange HPLC column using $6.5 \mathrm{mM}$ sodium sulfate as a mobile phase at $\mathrm{pH} 10.2$.

exchange column not all of the released As was detected (Fig. 6). Some fraction of the As was retained on the column when using sulfate as the mobile phase and there was therefore a shortfall in the As mass balance. One possible explanation is that this is because of DNA being such a large molecular species with many negative charges present, arising from the presence of phosphate groups in its backbone. ${ }^{30}$ These may become bound very strongly with the stationary phase of the column and not easily be eluted. Therefore the sum of As species in the chromatographic separation from the injected DNA extracts using HPLCICP-MS was lower than the total As measured from the extracts of DNA measured using ICP-MS. As a result one can hypothesise that these As 'species' which can be detected on the chromatogram are (i) only relatively weakly associated with the already well washed DNA molecules (because they can easily be removed from the DNA itself using only competitive sulfate ions) and (ii) that some of the inorganic $\mathrm{As}^{\mathrm{V}}$ made freely available during the extraction procedure may have become associated with the DNA despite intensive washing. The As which is retained on the column can be considered as integrated or strongly bound with the DNA, possibly part of the structure and which have potentially replaced phosphate linkages in the DNA from the plants. In this case, it may be conjectured that As possibly as arsenate, which is a phosphate analogue ${ }^{31}$ could replace phosphate in the DNA molecule's backbone when in a highly As-contaminated environment. This is consistent with Wolfe-Simon et al.' $\mathrm{s}^{32}$ study which suggested that arsenate could be a viable substitute for phosphate in the DNA of the Halomonadaceae GFAJ-1 strain which can grow in the presence 


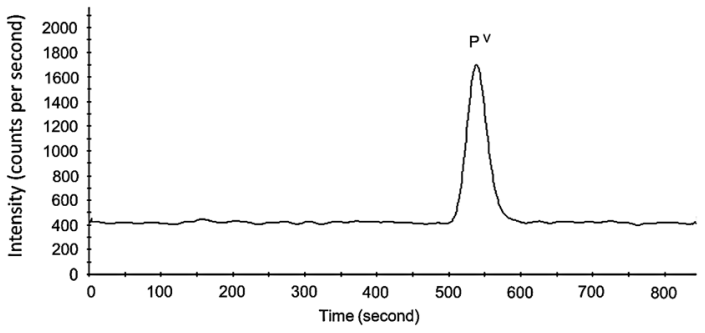

Fig. 7 Chromatogram of phosphate in aqueous solution. Phosphate $5000 \mu \mathrm{g} \mathrm{L}^{-1}$, employing a Hamilton PRP-X100 anion-exchange HPLC column using $6.5 \mathrm{mM}$ sodium sulfate as a mobile phase $\mathrm{pH} 10.2$.

of InAs ${ }^{\mathrm{V}}$ and possibly in the absence of suitable levels of phosphate.

A similar phenomenon occurred when the phosphate concentration from the same compartmentalised DNA extracts was measured. The concentrations of total $\mathrm{P}$ measured using ICP-MS in DNA extracts were higher than the $\mathrm{P}$ present as phosphate, determined using the same conditions as that used for As species determined using HPLC-ICP-MS (Fig. 8). These results are shown in Table 8.

3.5.2.5 Estimation of As incorporated within DNA extracts. From the root of the rice plant the total concentration of As in the $3 \times$ well-washed DNA extract, dissolved using Tris and EDTA buffer was $0.196 \mu \mathrm{g} \mathrm{g}^{-1}$ as shown in Table 8. This is in good agreement with the total As concentration in the extracted and $3 \times$ well-washed DNA, digested in $\mathrm{HNO}_{3}\left(0.188 \mu \mathrm{g} \mathrm{g}^{-1}\right)$. Arsenic, some $0.115 \mu \mathrm{g} \mathrm{g}^{-1}$ if assumed to be present as arsenate, was found to be weakly 'associated' with the DNA (Fig. 6). However, the concentration of As in the extracted DNA which may be incorporated strongly with the DNA itself (that which could potentially replace phosphate linkages) could be calculated by difference to be $\sim 0.081 \mu \mathrm{g} \mathrm{g} \mathrm{g}^{-1}$. The concentration of $\mathrm{P}$ as phosphate detected in the DNA extracts of the root of the rice after chromatographic separation was $98 \mu \mathrm{g} \mathrm{g} \mathrm{g}^{-1}$. This is considered to be phosphate just 'associated' with the DNA extract (Fig. 8). If the As 'incorporated' strongly with DNA is compared with the phosphorus as phosphate incorporated (integrated) within DNA $\left(217 \mu \mathrm{g} \mathrm{g}^{-1}\right)$ then the As incorporated within DNA is $0.03 \%$ of the phosphorus level (as phosphate in the DNA backbone) incorporated within the DNA extracted from the root of the rice plant. Reproducible results indicate that the

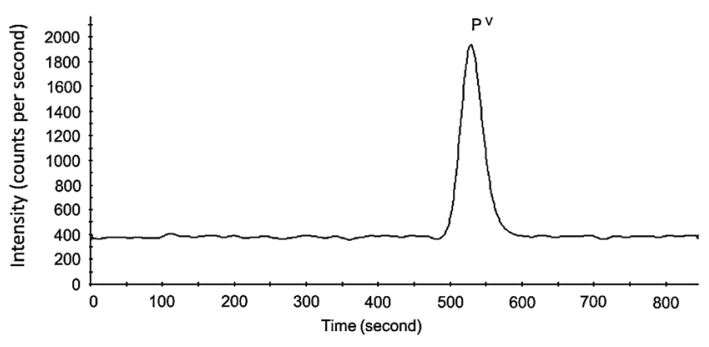

Fig. 8 Chromatogram of phosphate in DNA extracts from the root of the rice sample employing a Hamilton PRP-X100 anion-exchange HPLC column using $6.5 \mathrm{mM}$ sodium sulfate as a mobile phase $\mathrm{pH} 10.2$.
'As' associated with DNA from the root was $58.7 \%$ of the total As from the extracted DNA. The remaining As, incorporated strongly with DNA was some $41.3 \%$ of the total As in the extracted DNA.

In the stem, the total As concentration in the DNA extract was $0.072 \mu \mathrm{g} \mathrm{g}^{-1}$. Arsenic at $0.042 \mu \mathrm{g} \mathrm{g}^{-1}$, as arsenate was the only As species found to be just weakly associated with the DNA fraction. The remaining $0.030 \mu \mathrm{g} \mathrm{g}^{-1}$ of As, calculated by difference was incorporated strongly with the DNA from the stem; possibly replacing phosphate linkages. The As which is weakly associated with DNA represented a reproducible value of $58.3 \%$ of the total As from the extracted DNA while some $41.6 \%$ of As was 'incorporated' strongly with the DNA fraction. Finally, in the leaf of the rice plant, some $0.020 \mu \mathrm{g} \mathrm{g}^{-1}$ of As, was found to be just associated with the DNA structure while by difference $0.014 \mu \mathrm{g} \mathrm{g}^{-1}$ of As was calculated to be integrated strongly with the DNA fraction; possibly replacing phosphate linkages in the DNA from the leaf. The percentage of As associated with the DNA fraction was a reproducible $58.8 \%$ of the total As found in the extracted DNA in the leaf while the other fraction, some $41 \%$ was found to be incorporated strongly with the DNA fraction. It is of particular note that the ratio of the hypothesised to be 'incorporated' As in the DNA from the three independent compartments of root, stem, and leaf are all in the very close range $41 \pm 1 \%$. This value may tell us something about the coping strategy that a rice plant adopts to deal with As in highly contaminated environments. ${ }^{7,8,10,11}$

3.5.2.6 Removal of retained As and $P$ species from column. After several injections of DNA onto the column, an attempt to release the retained species was undertaken. A cleaning solution $\left(1 \%\right.$ of $6 \mathrm{M} \mathrm{HNO}_{3}$ in $\left.\mathrm{CH}_{3} \mathrm{OH}\right)$ which is recommended to clean but also to stabilise the Hamilton PRP-X100 column, was injected instead of the sample. Both arsenic as arsenate and phosphorus as phosphate were detected as coming from the 'retained DNA fraction' held on the column. Both these species (InAs ${ }^{\mathrm{V}}$ and phosphate) are considered to be strongly 'incorporated' with the DNA fraction. This harsh solution of acid (1\% $6 \mathrm{M} \mathrm{HNO}_{3}$ ) in alcohol was therefore beginning to strip the strongly bound As from the DNA together with phosphate, as the DNA was being denatured. This could be further evidence of how in high As bearing environments, plant phosphate linkage molecules in its DNA can be replaced by arsenic.

\subsection{Conclusion}

The determination of the total and extractable As content and As species in Iraqi rice plant samples together with that in the soil and irrigation water used to grow the plants was undertaken. The main As species in soil and plants analysed during this study were InAs ${ }^{\mathrm{V}}$ and InAs ${ }^{\mathrm{III}}$, while DMA and MMA were below the LOD (DMA 0.011 $\mu \mathrm{g} \mathrm{g}^{-1}$ and MMA $0.014 \mu \mathrm{g} \mathrm{g}^{-1}$ ) in plant samples. The distribution of total and As species in rice was in the order of root $>$ stem $>$ leaf $>$ grain with $\operatorname{InAs}^{\mathrm{V}}$ the predominant As species in all compartments of the rice plant. The Akre soil showed only inorganic As (total extractable, 2.88 $\mu \mathrm{g} \mathrm{g}^{-1} ; 86 \%$ InAs $^{\mathrm{V}}: 14 \%$ InAs $^{\mathrm{III}}$ ) present with this ratio being approximately maintained in each 'compartment' of the rice 
plant, root, stem, leaf and grain. Only $14.2 \%$ of the aqua-regia extractable soil As (some $0.41 \mu \mathrm{g} \mathrm{g}^{-1}$ ) may be considered "available" to the plant using the BCR method.

The novel study investigating the relationship between As species and selected cellular fractions including DNA showed that the DNA extracts of rice (including root, stem and leaf) contained As above the LOD $\left(0.019 \mu \mathrm{g} \mathrm{g}^{-1}\right)$. The concentration of total As in DNA extracts from the three compartments, from the root to the leaf of the same plant gave reproducible results and decreased with decreasing total As concentration of the plant. It was found that arsenic could become strongly incorporated with DNA, but to ascertain in which form would require further work. It was also found that there was a contribution from As, identified from column speciation studies as arsenate that is more weakly 'associated' with DNA in rice plant. This decreased with decreasing As concentration from the root to the leaf of the same plant. Finally, it was noted that the \% fractions of strongly 'incorporated' As with the DNA from the root, stem and leaf of the plant are all very similar, being a reproducible 41 $\pm 1 \%$ of the total As in the DNA extract.

\section{Conflicts of interest}

There are no conflicts to declare.

\section{Acknowledgements}

The authors would like to acknowledge their special thanks to The Ministry of Higher Education and Scientific Research in the Kurdistan region of Iraq for financing a PhD studentship for B. A. Sadee.

\section{References}

1 M. Abedin, M. Cresser, A. Meharg, J. Feldmann and J. CotterHowells, Environ. Sci. Technol., 2002, 36, 962-968.

2 F. Ozturk, F. Duman, Z. Leblebici and R. Temizgul, Environ. Exp. Bot., 2010, 69, 167-174.

3 J. Ma, N. Yamaji, N. Mitani, X.-Y. Xu, Y.-H. Su, S. McGrath and F.-J. Zhao, Proc. Natl. Acad. Sci. U. S. A., 2008, 105, 9931-9935.

4 B. Mandal and K. Suzuki, Talanta, 2002, 58, 201-235.

5 M. Quaghebeur, Z. Rengel and M. Smirk, J. Anal. At. Spectrom., 2003, 18, 128-134.

6 O. Muñoz, O. Diaz, I. Leyton, N. Nuñez, V. Devesa, M. Súñer, D. Vélez and R. Montoro, J. Agric. Food Chem., 2002, 50, 642647.

7 M. Vandegehuchte and C. Janssen, Mutat. Res., Genet. Toxicol. Environ. Mutagen., 2014, 764, 36-45.

8 A. Ghiani, P. Fumagalli, T. Nguyen Van, R. Gentili and S. Citterio, PLoS One, 2014, 9(6), e99239.

9 E. Smith, A. Juhasz, J. Weber and R. Naidu, Sci. Total Environ., 2008, 392, 277-283.
10 M. Heidari, Zemdirbyste-Agriculture, 2017, 104(4), 369-376.

11 I. F. S. Alvarenga, F. E. dos Santos, G. L. Silveira, L. F. Andrade-Vieira, G. C. Martins and L. R. Guimarães Guilherme, Sci. Total Environ., 2020, 698, 134272.

12 ISO11466, Soil quality - Extraction of trace elements soluble in aqua regia, International Organization for Standardization, Geneva, 1995.

13 G. Rauret, J.-F. López-Sánchez, A. Sahuquillo, E. Barahona, M. Lachica, A. Ure, C. Davidson, A. Gomez, D. Lück and J. Bacon, J. Environ. Monit., 2000, 2(3), 228-233.

14 S. Garcia-Manyes, G. Jiménez, A. Padro, R. Rubio and G. Rauret, Talanta, 2002, 58(1), 97-109.

15 C. Lou, W. Liu and X. Liu, J. Chromatogr. B: Anal. Technol. Biomed. Life Sci., 2014, 969(10), 29-34.

16 G.-X. Sun, P. Williams, Y.-G. Zhu, C. Deacon, A.-M. Carey, A. Raab, J. Feldmann and A. Meharg, Environ. Int., 2009, 35, 473-475.

17 C. Nunes, J. Ferreira, M. Fernandes, S. Breves, A. Generoso, B. Soares, M. Dias, M. Pasqual, A. Borem and G. Cançado, Cienc. Rural, 2011, 41, 1383-1389.

18 R. Ibrahim, Gene Conserve, 2011, 10, 165-182.

19 R. Chen, B. W. Smith, J. D. Winefordner, M. S. Tu, G. Kertulis and L. Q. Ma, Anal. Chim. Acta, 2004, 504(2), 199-207.

20 Commission Directive 2003/40/EC of 16 May 2003 constituents of natural mineral and spring waters, 2003, Off. J. Europ. Union, EN, L 126/34.

21 M. Giral, G. J. Zagury, L. Deschênes and J.-P. Blouin, Environ. Pollut., 2010, 158(5), 1890-1898.

22 C. K. Jain and I. Ali, Water Res., 2000, 34(17), 4304-4312.

23 L. Jedynak, J. Kowalska, M. Kossykowska and J. Golimowski, Microchem. J., 2010, 94(2), 125-129.

24 L. Jedynak, J. Kowalska, J. Harasimowicz and J. Golimowski, Sci. Total Environ., 2009, 407(2), 945-952.

25 A. Signes-Pastor, K. Mitra, S. Sarkhel, M. Hobbes, F. Burló, W. De Groot and A. Carbonell-Barrachina, J. Agric. Food Chem., 2008, 56(20), 9469-9474.

26 Y. Zavala and J. Duxbury, Environ. Sci. Technol., 2008, 42, 3856-3860.

27 M. A. Alvarez and G. Carrillo, Talanta, 2012, 97, 505-512.

28 I. De Gregori, E. Fuentes, D. Olivares and H. Pinochet, J. Environ. Monit., 2004, 6(1), 38-47.

29 C. Gleyzes, S. Tellier and M. Astruc, TrAC, Trends Anal. Chem., 2002, 21(6), 451-467.

30 Y. Takasaki, S. Sakagawa, K. Inagaki, S.-I. Fujii, A. Sabarudin, T. Umemura and H. Haraguchi, Anal. Chim. Acta, 2012, 713, 23-29.

31 A. Meharg, Trends Plant Sci., 2004, 9, 415-417.

32 F. Wolfe-Simon, J. Blum, T. Kulp, G. Gordon, S. Hoeft, J. PettRidge, J. Stolz, S. Webb, P. Weber and P. Davies, Science, 2011, 332, 1163-1166. 